\title{
An Inclusive Secondary School in Bratislava
}

\section{Eva Gajdošová - Veronika Bisaki - Silvia Sodomová ${ }^{*}$}

\author{
Received: August 21, 2016; received in revised form: October 1, 2016; \\ accepted: October 2, 2016
}

\begin{abstract}
The study presents a characterization of an inclusive secondary school in Bratislava and provides information about the forms and methods used in the work of the teachers, school psychologists, special teachers with regard to students with special needs (students with Attention and Hyperactivity Disorder, i.e. ADHD, with learning difficulties, with emotional and behaviour difficulties, etc.), who are educated together with mainstream students. It also provides information on the first results of the measurements of the socio-emotional health of the students in the inclusive school, both as to its overall level (covitality index) and as to the level of the four psychological dimensions of mental health. The pilot project of the inclusive school confirms that inclusive secondary schools and inclusive education operating within the intentions of positive psychology help the students to develop their cognitive and socio-emotional competences, to create favourable attitudes to diversity, to form the students' scale of positive values and to encourage positive interpersonal relationships, social cohesion and social classroom climate.
\end{abstract}

Key words: inclusion, inclusive school, multidisciplinary team, school psychologist, social-emotional health.

\section{Introduction}

The area of inclusive education is the mater of not only some states, but it is incorporated into the agenda of supranational organizations as UNO, UNESCO and the European Union. These institutions have the largest share in making the inclusive policy part of the policies of all states and in directing the transformation of the school systems towards inclusiveness.

\footnotetext{
Eva Gajdošová, Paneuropean University, Bratislava, Slovakia; eva.gajdosova@paneurouni.com Veronika Bisaki, Paneuropean University, Bratislava, Slovakia; nikanika84@gmail.com Silvia Sodomová, Paneuropean University, Bratislava, Slovakia; silvia.sodomova@gmail.com
} 


\section{Acta Technologica Dubnicae \\ volume 6, 2016, issue 3}

In Slovakia, its ratification took place in the year 2010 and, in November 2011 when the government of the Slovak Republic signed the membership of the Slovak Republic in the European Agency for the Development of Special Needs Education, which enabled its becoming part of the international expert platform supporting the development of inclusive education within which the school respects the diversity and individuality of children. The problem of inclusion in education in Slovakia started to be defined namely after January 2012 when the government of the Slovak Republic adopted the conception of inclusive education, and, consequently, in February 2012, it pointed out the need for legislative specification of the notions of segregation and inclusion in the Antidiscrimination Act, in the Act on Education, and in the ensuing relevant legislation. In the conception of education dated January 11, 2012, it was stated that it is necessary to work out "a specified model of school inclusion for various situations and target groups with the ambition of creating a general model of inclusive schools". Only as late as at the beginning of the year 2014, the first model of inclusive schools was worked out and defended within the Project of Inclusive Education (PRINED) and, at present, it is being tested at about one hundred elementary schools, but only within the Roma ethnicity in Slovakia. An important role in the project of inclusive schools is played by the "inclusive team" at the school where, in addition to the teaching staff, also a school psychologist, a special teacher, a social worker, assistant teachers, and in the case of need also other specialists work.

UNESCO defines inclusive education as a process reacting to the diversity of the needs of all the pupils by means of increasing their participation in education. Daniels and Garner (1999), experts in the field, stressing the notion of inclusion point out the fact that the shift from integration to inclusion does not only mean a terminological shift which would be a result of political correctness, but it means a principal change of the perspective. It means a shift from a deficit model which is based on the premise that the difficulties and problems have their origin in the child, to a social model which states that barriers in learning exist in the very school structures and, more generally stated, in the attitudes and structures of the whole society. The inclusive approach stresses the premise that each child has the right to participate in everything that is offered in an ordinary class.

Nielsen (2014), a psychologist from Copenhagen, stresses the need to fulfil four conditions so that a school could be denoted as an inclusive school. They are the following ones: attendance, acceptation, participation and success.

Attendance concerns the time that students with special needs spend at classes in an ordinary school. 


\section{Acta Technologica Dubnicae \\ volume 6, 2016, issue 3}

Acceptation concerns the attitudes of the classmates as well as of the teachers and their acceptance of children with special needs as active members of a class as a group of studentss in an ordinary school.

Participation means that children with special needs actively take part in all school activities.

Success means that children with special needs are enabled to experience success at school and develop a positive image of themselves.

Hence, at a school which is inclusive, students are not merely present in the classroom, just sitting there, but they are incorporated in the activities of the class, are accepted by their classmates and teachers, are praised, experience success, get feedback with regard to what they are good at and what the special strength of their personality are.

Also, according to Vančová (2008, p. 10), the application of the principle of inclusion means "creation of conditions for people with a disorder to fully participate in all social activities which are open to people without any disorder". The inclusive form of education represents the possibility of joint education of students with special educational needs together with mainstream students (Schmidtová, 2013). In real educational situations, this means that the jointly educated students in one "inclusive" class can be mainstream students and:

- Students with health disorders,

- Students who are ill and have impaired health,

- Students with developmental disorders,

- Students with behaviour difficulties,

- Students from a socially deprived environment,

- Talented students (Internal Methodological Material of the State School Inspection, 2014).

Nevertheless, as further stated by Schmidtová (2013), although today, in the territory of the Slovak Republic, we have the so-called pro-inclusive education, so far it is actually perceived with mixed feelings by all the parties concerned, which stems from the ideas on the direction of education on the systemic level that have not been fully specified. The author also stresses that the current situation in education requires the implementation of a humanistic-creative philosophy of holistic approaches to education with regards to all the students, in particular to students with special educational needs. 


\section{Acta Technologica Dubnicae \\ volume 6, 2016, issue 3}

\section{Methods}

\subsection{Characteristics of the inclusive secondary school}

The secondary school with socially-oriented studies is a school with a pilot inclusive education. The educational process takes place within the 1st through the 4th class, each with only a few students (8-15 students in a class) aged 15-19. The mainstream students are educated together with students with special needs, above all with students with the diagnosis of specific developmental learning disorders (above all with dyslexia, dysorthography, and dyscalculia) and with emotional disorders (e.g. with activity and attention difficulties, with depressive behaviour disorder, with phobic anxiety disorder, and with elective mutism).

Students with learning and behavioural disorders entered the school with negative experiences from their school life at elementary schools, and many of them also with experiences of verbal and physical bullying, cyberbullying and violence.

We supposed that as a result of applying non-traditional, humanistically oriented forms, methods and procedures in education, and of applying positive psychology at school, above all by building a new relationship between the teacher and the student, with stress on the positive aspects and on the potential of the student, with the services of school psychologist and special teachers directly within education, not only the level of the cognitive development of students will be increased, but the level of personal and above all socio-emotional development will be considerably increased, too.

The personality of each student of the school, their uniqueness, originality and specificity are respected during education. In the process of education, each student is treated individually, taking into consideration the specific features of their psychic setup, the capacity of perception, memory, thinking, problem solving, their will, temperament, giftedness and talent, and the methods, procedures and the approach of the teachers are adopted to the above. In the school, there is a distinct tendency to search for the strong points and the potential of each student, including students with a handicap.

\subsection{Primary principles of the school}

The functioning of the school is based on the following five principles: cooperation, communication, competence, creativity, and career.

The cooperation principle applied in the inclusive type of school stresses the cooperation of all the partners - the participants of the educational process - in promoting the educational development of the strong points and the creation of a firm multidisciplinary team in the school. A school with inclusive education 


\section{Acta Technologica Dubnicae \\ volume 6, 2016, issue 3}

needs a multidisciplinary cooperation of several specialists, both educationalists and experts, above all teachers, special teachers, a school psychologist, but as a part of external cooperation also clinical and advisory psychologists, psychiatrists and speech therapists.

The school psychologist and teachers meet and cooperate to promote the optimum social and emotional development of students. Within that cooperation, the psychologist's activities and procedures rely on the data, evaluation and the results of the pedagogical diagnostics undertaken by teachers, while, on the other hand, teachers make use of the psychological analyses and carry out the proposals of the school psychologist. At the same time, it needs to be borne in mind that teachers always remain the leading personalities in the educational process as most of the positive psychological interventions into the personality development of children and youth is realised by means of the activities of teachers.

The principle of communication - while in a traditional school, informal communication more often occurs among people of the same social status, in inclusive secondary schools, communication is open within various directions, i.e. in the direction towards the management of the school, as well as in the direction towards the students and their parents. Direct communication between the teachers and the students with expressing emotions and feelings openly, openness and discussion within submitting proposals, comments, and ideas, and cooperation in solving problematic situations are characteristic for the school. The relationships among the teachers, as well as the relationships between the teachers and the students, and the teachers and the parents are based on cooperation and partnership.

As the standards in an inclusive type of school incorporate pluralism and variety, the individuals are also prepared for the fact that, in the school, there will also occur problems and conflicts, and that their own opinions as to solving problems will be exposed to open criticism, often in disagreement with their opinions. At the same time, here it is accepted that each problem is to be solved jointly, in cooperation with others, and that in searching for the solutions, the interests of other people in the school are always taken into consideration.

The climate of trust, friendship, openness, discussion of ideas, informality and closeness are among the characteristics of an inclusive secondary school. The school tolerates diversity and supports the heterogeneousness of ideas, proposals and solutions, and the variedness of pedagogical applications, new ways of handling matters including some radical ways, while mistakes are considered a part of the experiment, and also from such an experience teachers draw lessons. 


\section{Acta Technologica Dubnicae \\ volume 6, 2016, issue 3}

The role of the school psychologist is to assist in the exchange of opinions between the teachers and students, between the teaching staff and the groups or classes of students, to assist in direct, open, free and authentic communication among all the participants of the educational process, in organizing public discussions concerning the social dynamism of the groups, the social relationships, the solution of conflicts and improving the social class climate, and to assist in a critical evaluation of the organization and the management of the school by the teachers and the students. The management of the school makes decisions concerning the school and the educational process only after having discussed the possible proposals for solutions with all the participants, i.e. not only with all the teachers, but also the students.

The principle of competence foregrounds the fact that, in education, stress is laid not only on the development of the required knowledge, skills and habits of the students, i.e. their specialized competence, but above all on their socialemotional competence necessary for their appropriate functioning among people. It is generally known that social skills are extremely important in the school environment as they have their share in the general good functioning of the students at school, in their ability to participate in teamwork and being able to solve problems individually, openly express their feelings and opinions, have a positive attitude to themselves as well as to people around them, raise questions, and formulate arguments. Secondarily, their social skills are also reflected in their efficiency and success at school. Experience testifies to the fact that students who have a low level of social competence and social skills more frequently have behaviour problems at school with negative consequences upon their attitudes to school, to learning and to teachers, and, consequently, also have problems in learning.

Within the courses of Social Psychology and Social-Psychological Training, which are included into the syllabi, the focus is mostly on the development of the so-far neglected competences stressed above all by positive psychology as, e.g. altruism, philanthropy, team cooperation, belief in self, belief in others, stress management, solving conflicts and crises, wellbeing, responsibility, solidarity and spirituality. Schools aim at including the teachers as well as the parents into developing the social-emotional competences by means of shortterm training, workshops, debates and discussions.

School psychologists get involved in this part, too, as they can help students form, develop and use adequate social skills at school, in their relationships with their classmates, teachers and other pedagogical staff, as well as to their parents and to the people in their wider social environment. 


\section{Acta Technologica Dubnicae \\ volume 6, 2016, issue 3}

Creativity is the principle which stresses the development of students' creativity and creative thinking. It requires the identification of their individual abilities, giftedness and talent that gradually get further developed within education. Creativity is one of the highest ranking competences which can be applied within the educational process, as well as within self-education and selfdevelopment (Zelina, 2014).

At a secondary school of the inclusive type, it is presupposed that each student is gifted and talented in something and that by finding out and by developing these specific abilities, their self-confidence and belief in self can be increased, and that students can find their place among their classmates, experience success, head towards their future profession, etc.

The principle of career means to provide systematic and qualified assistance in decision-making and in the selection of the students' profession in compliance with their personal potential as well as the requirements of the labour market.

The process of school selection, the choice of the fields of study, specialization and profession are another area which requires an intensive cooperation and mutual coordination of activities of the class teachers, the school counsellor and the school psychologist with the students and their parents. All these persons involved in the decision-making process related to the appropriate selection of young people's profession share a common goal, i.e. an optimal harmonization of the interests and the preferences of students, their personal strength and potential for the selected profession with the current requirements of the labour market, social demands, and the supply of jobs so that both students and the society can profit from the situation.

\subsection{Specific principles of the school}

Students are in the centre of the school and their individuality, uniqueness and special character are respected.

Students with specific needs necessitate a school with a flexible structure and with alternative teaching methods. A low number of students in classes, acceptation of their differences, their special character, individuality and otherness are of importance, too. This way, students get into the focus of all the teachers' attention, of the special teacher and of the school psychologist. Teachers accept students without any prejudices and treat them equally.

Each student experiences success, appraisal and appreciation at school.

In an inclusive school, which has classes with a lower number of students, teachers can pay much more attention to particular students and help them with problematic areas. In such an environment, each student has a bigger chance to make his or her mark, to discuss things with the teacher and to show what is in 


\section{Acta Technologica Dubnicae \\ volume 6, 2016, issue 3}

him or in her. In such a school, students give more encouragement to each other, they help each other and they have the feeling of togetherness. Each student experiences success and joy, and this way, they acquire a positive attitude to school. Students are often praised for everything that they do well, even if it is only a trifle. In this way, learning becomes joy and not an obligation.

There is a family and friendly climate at the classes.

The inclusive school creates a relaxed climate for their students. They start each day with a dialogue. The school class itself is different from the one that we know from traditional schools. Students with specific needs are not pushed towards an exact delimitation of the structure of the class as they cannot hold their attention for a long time. Hence, during the classes, they can also relax, e.g. by listening to music, by drawing, or else they can walk around, or visit the psychologist or the special teacher.

\section{Grades serve for positive motivation.}

In the inclusive school, students are not randomly called out and examined. If a student has learned a topic, he or she can ask to be examined. If the student has dysgraphia, dysorthography or some other problems with writing, he or she is not forced to take written tests, but is always tested orally. Students are graded on the classical scale, while worse grades are given only exceptionally. If a student wishes to try to improve his or her grades, teachers always appreciate such an intention and examine the student. In some cases, only verbal classification is used. The decision on the final grade is always discussed by the teacher, special teacher, and the school psychologist. Hence, the final grade is not the average of the grades, but it reflects the overall work of the student during the school year, his or her activity, effort, motivation and progress are considered.

\section{Projects within the educational process.}

The inclusive school has implemented several programmes into the process of education. Let us mention at least the preventive programme of the development of emotional intelligence the characteristics of which we present further on. The preventive programme is directed upon pro-social education and upon the development of the social skills and emotional intelligence of the students. The students learn to get to know themselves, the people around them, to communicate better with them, to handle negative emotions, and to solve conflicts more adequately. By means of model situations, they learn to develop their social communication, empathy and to control their emotions as bad temper, anxiety and anger. 


\section{Acta Technologica Dubnicae \\ volume 6, 2016, issue 3}

\section{Work of a multidisciplinary team.}

The secondary school has a special teacher, a school psychologist and, in case of need, also an assistant teacher, who are at the disposal of the students during the process of education. They help them in learning, as well as in the development of their personality, they encourage and appreciate students, they support their belief in self, they are their confidants and good friends always ready to listen to them and help them.

\subsection{Educational strategies}

In the educational process, in the inclusive secondary school, the following new features are applied:

- the organization of the educational process;

- mutual relationships between teachers and students, but also mutually among the teachers and other pedagogical staff;

- a considerable participation of the school psychologist directly in the educational process and in the systematic everyday cooperation with the teachers, students, parents and the school counsellor.

\subsubsection{Organization of the educational process}

In the educational process, several new elements of organization and management contributing to fulfilling the goal of the experiment are applied:

- 90-minute classes for major subjects (Mathematics, Slovak language and literature, English language, Psychology, Education, Sociology, SocialPsychological Training, Methods of Social Work);

- Alternating 45-minute and 90-minute classes within the timetable;

- Optimally alternating "easier" and "more difficult" subjects, and scheduling the more difficult subjects so that, in the timetable, they occur on the days and at the hours of the highest activity of the students (Tuesday, Wednesday, Thursday, the 2nd through the 4th class);

- Stress is laid on short and long breaks and on lunch breaks;

- Beginning the classes by a meeting of the school psychologist with students, where the atmosphere for a peaceful, unstressed beginning of classes will be prepared;

- Absence of ringing at the beginning and at the end of classes and before breaks, and the possibility to shorten or extend the classes depending on the tiredness or the motivation of the students. 


\section{Acta Technologica Dubnicae \\ volume 6, 2016, issue 3}

\subsubsection{Didactic forms and methods of teaching}

The focus is on problem-oriented teaching, within which individual and creative thinking of students is developed together with their constructive imagination, and concentration of attention and perception. Group forms of work, competitions, games and team work are often used in the educational process.

Differentiated education and differentiation of students based on their abilities, interests, and talent is carried out in the form of facultative subjects of differentiated education in the class depending on their interests (i.e. of groups as well as of individuals). The starting-point for teachers is their knowledge of their students' personalities, which is mediated to them by the school psychologist and the special teacher.

From among the frequently used activation methods, we can mention directed dialogues, discussions, talks with invited specialists, excursions, doing independent or team work, experiments and practical exercises. The principles of exemplification, adequacy, sequentiality, systematic activities, scientism, particularity and activity are respected. In addition to the traditional methods of written tests, knowledge assessment is also carried out in the form of didactic tests. The general and the intellectual abilities of students, their personality traits, interests and attitudes are identified by using standardized assessment methods.

\subsubsection{Teacher - student relationship}

In addition to professional knowledge, the zeal and the experience of a teacher with the application of new, non-traditional elements in the educational process, and a positive approach to students based on friendly relationships are decisive for the selection of teachers for an inclusive-type school.

The teacher selection criteria are:

- Mature and healthy personality of the teacher without any pathological elements;

- Pedagogical-psychological mastery, experience in applying the psychological aspects in education, application of non-traditional activation forms, methods and approaches in the educational process, and a creative approach to teaching;

- Good communication skills and respecting students' personalities.

\subsubsection{The role of the school psychologist and his or her activities at school}

The main mission of the school psychologist is to contribute to the development of the personality of each student in the school and to the mental health of students by optimizing the school as a system. The school psychologist participates in solving the problems and difficulties of the students in learning, in their conduct, and in decision-making. With regard to their profession, they 


\section{Acta Technologica Dubnicae \\ volume 6, 2016, issue 3}

assist in improving the impaired social relationships between the teachers and the students, as well as in providing for the creation of psycho-hygienic conditions of the educational process.

The school has a school psychologist who is at the disposal of students during the process of education, he or she helps them in developing their personalities, encouraging and appreciating the students, supporting their belief in self.

School psychologists help inclusive schools in the most sensitive areas, not only in solving everyday problems in students' development and education, but also in supporting the mental health of teachers and students, in creating a healthy social climate in the school and good interpersonal relationships within the school environment, in providing the cooperation of the school and the families of students, in introducing non-directive methods of education, while taking into consideration the specific age and development-related features of the students, they help the teachers in getting to know the personality of each student, in introducing development and intervention programmes for the prevention of aggression, force, bullying, intolerance, racism, and in introducing programmes for the development of emotional intelligence and pro-social behaviour.

At an inclusive school, within primary prevention, the activities of a psychologist also include the following (Bisaki et al., 2014):

- Improving the social atmosphere and the climate in the school and in individual classes, improving the interpersonal relationships in the team, among the teachers and the students, aiming at better mutual acceptation, friendship, trust and partnership;

- Seeing to the psycho-hygiene of learning and of education;

- Improving the social skills of students, their problem-solving, stressmanagement, managing negative emotions and strain;

- Developing the social competences of teachers and promoting effective solutions of conflicts between the students and their parents;

- Increasing the psychological qualifications of the teachers and the students' parents (e.g. by discussions and lectures on selected psychological themes, e.g. "How to motivate students studying below their abilities", etc.);

- Getting to know the learning styles of students and their connectedness with the manner of teaching, and the procedures and approaches of the students;

- Teaching the teachers how to succeed in better knowing the personalities of their students, to carry out adequate pedagogical diagnostics and selection of interventions for working with problematic students (e.g. with students who are hyperactive, aggressive, not progressing, or else with talented and gifted students, etc.); 


\section{Acta Technologica Dubnicae \\ volume 6, 2016, issue 3}

- Devoting special attention to gifted and talented students and psychological preparation of teachers for working with these students;

- Professional orientation of students and their preparation for an appropriate selection of a university and of their profession;

- Carrying out preventive and developmental programmes primarily aimed at the development of the emotional intelligence of students, they learn better to know themselves and the others, to solve problems successfully, to communicate with their social environment adequately, reduce violence, be tolerant, and develop assertive behaviour.

In an inclusive school, the role of social psychology is important. Especially the social factors such as the social school and class climate, the social cohesion of school classes, social competences, self-perception and belief in self, attitudes to the school, classmates and to their own self, and the social-emotional health which are decisive not only for the success of students at school, but also for their satisfaction, for their wellbeing and their happiness.

\subsection{Preventive programme for the development of emotional intelligence of secondary school students}

As a starting-point in developing this programme, we used the conception of emotional intelligence by D. Goleman $(1997,1998)$ as well as his recommendations and suggestions for carrying out preventive programmes of emotional (personal) intelligence development in schools.

As the above authors suggest, within the preventive programme, the students should acquire:

A. Emotional skills (identification of emotions, manifestation of emotions, control of emotions and impulses, reduction of stress, awareness of the differences between emotions and deeds);

B. Cognitive skills (self-consciousness, healthy self-esteem and belief in self, understanding the attitudes and opinions of other people, showing respect for the norms of behaviour, for the application of constructive approaches to problem-solving, to effective conflict-solving, and to a positive attitude to life);

C. Behavioural skills (verbal as well as non-verbal communication, application of the techniques of active listening, open assertion of their own opinions and requirements, and constructive reactions to criticism).

These most important elements of effective preventive programmes of development have been included into our one-year programme of the development of emotional intelligence of primary school students and of its integral part - the programme of effective conflict-solving. 


\section{Acta Technologica Dubnicae \\ volume 6, 2016, issue 3}

The development of the above three types of skills in our programme aims at the following goals:

A. Cognitive skills

- Improved self-knowledge, self-consciousness;

- Developing healthy self-esteem and belief in self;

- Getting to know other people, understanding their attitudes and opinions;

- Application of constructive procedures in problem-solving;

- Effective conflict-solving in the school and at home;

- Development of positive life attitudes.

B. Behavioural skills

- Acquisition of fundamental capabilities of interpersonal communication (both verbal and non-verbal);

- Acquisition of social skills for optimum inter-personal communication in peer groups;

- Application of the techniques of active listening;

- Open expression of views and requirements;

- Constructive response to criticism;

- Self-assertion.

C. Emotional skills

- Identification of emotions;

- Manifestation of emotions to other people, especially to peers;

- Control of emotions and impulses;

- Understanding the differences between emotions and deeds;

- Coping with stress.

Consequently, all the above goals found their reflection in the structure and the contents of the programme.

2.5.1 Structure of the programme at the inclusive school Module I

Getting to know oneself and getting to know the classmates, interpersonal perception, social sensitivity in interpersonal relationships in class (Getting to know personality traits, ways of experiencing situations, reaction and behaviour).

Module II

Verbal and nonverbal communication in class (Barriers to communication, possibilities of effective communication).

Module III

Conflicts in interpersonal relationships in class and their effective solution (Appropriate reactions in a stressful crisis). 


\section{Acta Technologica Dubnicae \\ volume 6, 2016, issue 3}

Module IV

Tolerance (Developing good interpersonal relationships in class without stereotypes, prejudice, discrimination and violence).

Module V

Cooperation of the classmates in class (Creating cooperative interpersonal relationships in class).

Within the particular modules, the programme stresses the following:

- Improvement of social perception - this concerns achieving a more differentiated perception of the reality. During the training process, we intentionally direct the students' attention towards the relationships of the students in classes, communication and behaviour, and we lead them to increasing their social sensitivity and to achieve a more differentiated ability of perception.

- Improving social skills - communication skills and constructive ways of solving interpersonal conflicts, abilities of cooperation, empathy, altruism, etc.

- Changing undesired stereotypes - revaluation of the adequacy of the so-far existing social habits and searching for new appropriate forms of social behaviour jointly.

- Deepening the knowledge of self and the knowledge of others - within training situations, favourable conditions are being created for a more thorough knowledge of oneself and of others. The limits of what the students know about themselves and of what the others know about them are shifted. A satisfactory social interaction can only take place when individuals possess sufficient information about themselves and about those with whom they are in interaction.

- Mediating insight - increasing the quality of understanding of oneself in relation to others, of relationships to others, of behaviour, attitudes, social relationships, social needs, insight into the process of own socialization.

- Optimization of self-regulation of behaviour - the experience that own behaviour can be at least partly regulated and changed leads students to realizing that in their social behaviour, they have certain possibilities of selection and to taking responsibility for this selection. The autonomy of students is being reinforced.

- Functional expression of feelings and emotions - this also includes the realization of each student's feelings and emotions and their verbalization. Emotions are of the same importance as thinking. Training supports experiencing emotions more intensively, but those who give full vent to their feelings should concentrate on increasing their self-regulation.

- Interpersonal openness - open self-presentation. The openness of a student increases the trust of the others and leads to mutually open communication. 


\section{Acta Technologica Dubnicae \\ volume 6, 2016, issue 3}

Openness should be selective; we should realize that in each social situation the frontiers of openness differ.

- Self-acceptation and acceptation of others - orientation towards own social behaviour, confrontation with own limitations and possibilities leads to realizing the relationship between the student and his/her self, and a safe atmosphere of training situations enables own acceptation. Self-acceptation and acceptation of others help in doing away with internal defence, and they contribute to the acceptation of others, to tolerance to their opinions and experiencing.

- Understanding the social relationships in the group - understanding the dynamism of a small social group and the inherent laws of the development of the group.

\section{Results}

We present the first results of the pilot research aimed at the identification of social variables and of social-emotional health of the students of the inclusive secondary school

We were curious to see what the level of the selected social variables (social status of the students, the degree of their loneliness and social dissatisfaction, evaluation of own success at school and their social-emotional health) among the students at this secondary school of inclusive type is.

For measuring the social-emotional health of students we used the Social Emotional Health Survey SEHS-S by M. J. Furlong, Professor from California University, Santa Barbara.

The SEHS-S questionnaire (Furlong et al., 2014) contains 34 items and the students were assessed within a four-item scale from 1 (completely untrue) to 4 points (completely true). When evaluating the questionnaire, we concentrated on finding the level of health in four domains: belief in self, belief in others, emotional competence and engaged living. In Slovakia, this is a completely new diagnostic means for measuring social-emotional health, not yet standardized with regard to the conditions in Slovak schools. The reliability of the SEHS questionnaire, as well as of the particular subscales, is acceptable or even good, which means that we can consider this questionnaire to be a reliable measuring tool. The reliability of the scale of social-emotional health has reached the value $\alpha=0.880$. 
Table 1

Reliability of the scale of social-emotional health

\begin{tabular}{|c|c|c|c|c|c|}
\hline & $\frac{\frac{\text { Social- }}{\text { emotional }}}{\underline{\text { health }}}$ & $\frac{\text { Belief in }}{\underline{\text { self }}}$ & $\frac{\text { Belief in }}{\text { others }}$ & $\begin{array}{c}\text { Emotional } \\
\text { competences }\end{array}$ & $\frac{\text { Engaged }}{\underline{\text { living }}}$ \\
\hline $\begin{array}{l}\text { Cronbach's } \\
\text { alpha }\end{array}$ & $\overline{0.880}$ & 0.707 & 0.744 & 0.653 & 0.799 \\
\hline $\begin{array}{l}\text { Number of } \\
\text { items }\end{array}$ & 36 & 9 & 9 & 9 & 9 \\
\hline
\end{tabular}

For measuring other social variables, we have selected the following well-known and generally used questionnaires: the socio-metric Questionnaire of awareness of success in school (Matějček \& Vagnerová, 1992) and the Questionnaire of loneliness and social dissatisfaction LSDQ (Asher-Wheeler, 1985).

Within the research, we were above all interested in what the level of the socialemotional health of the students of the selected secondary school is, both in general and in four basic domains (belief in self, belief in others, emotional competence and engaged living), and we also examined the selected variables.

\subsection{The overall level of social-emotional health}

The overall level of mental health is expressed by the index of covitality. On the basis of the analysis of the obtained research results we can state that only $10 \%$ of the students of the inclusive school $(\mathrm{N}=3)$ have a low level of socialemotional health. The mental health of the others is within the following average levels: $38 \%$ students $(\mathrm{N}=11)$ on the level of lower average, $41 \%(\mathrm{~N}=12)$ on the level of higher average. A distinctly high average of covitality was achieved by $10 \%(\mathrm{~N}=3)$ of all the participating students.

As for the overall level of socio-emotional health, there was no statistically significant difference between the mainstream students and the integrated students with regard to learning disorders and conduct. The index of covitality representing the level of socio-emotional health blocked was on the level of higher average. Neither has the statistical analysis of the results shown any significantly important differences between boys and girls, including the overall level of mental health and the level of the indicators. 


\section{Acta Technologica Dubnicae \\ volume 6, 2016, issue 3}

\subsection{The level of the basic psychological dimensions of social-emotional health}

\section{Belief in Self}

The analysis of the results has brought to our attention that as many as 59\% $(\mathrm{N}=17)$ tested students have a high belief in self and $41 \%(\mathrm{~N}=12)$ have an average belief in self. This is a very gratifying result for the teachers and for the experts of the school, as it indicates that the educational approach of the school leads to developing healthy belief in self.

\section{Belief in Others}

In addition to belief in self, we were also interested in the results in another dimension of the social-emotional health, namely the belief in others. Again, the results are very encouraging, as many as $76 \%$ of the students of the tested sample $(\mathrm{N}=22)$ show a high belief in others, $21 \%(\mathrm{~N}=6)$ denoted their belief in others as medium, and only $3 \%$ do not have belief in others.

\section{Emotional Competence}

Another psychological dimension of the mental/socio-emotional health is emotional competence. Again, as many as $79 \%$ of students $(\mathrm{N}=23)$ of the school evaluate their emotional competences as being very high and $21 \%(\mathrm{~N}=6)$ considered them to be average. It is also noteworthy that none of the participants denoted his or her emotional competences as being low.

\section{Engaged living}

Engaged living as another psychological dimension of mental health, is evaluated by as many $66 \%$ the students $(\mathrm{N}=16)$ as high, $31 \%$ of those tested $(\mathrm{N}=9)$ consider their engaged living as being average, and, similarly, 3\% consider it as being low. It is evident that namely in this area a number of students have certain limitations and reserves.

The results of the research concerning the overall level of socio-emotional health and its indicators were surprising for us. We did not expect that a school of inclusive type where mainstream students are educated together with integrated students who have specific developmental disorders in learning or have behaviour and emotional disorders, which requires the application of more demanding teaching styles and educational impact by the teachers, we shall find that in the case of nearly all students $(90 \%)$ the index of covitality is on a high level or on an average level. We were similarly surprised by the level of the particular indicators of mental health, above all of belief in self, belief in others and of emotional competence which is high or average, none of the students having a low level of it. 


\section{Acta Technologica Dubnicae \\ volume 6, 2016, issue 3}

These results testify to the fact that the conception of inclusive secondary schools and their orientation upon humanistic and positive psychology brings fruit in the form of a high level of mental health of students, their social emotional competences and of handling emotions by them. We can see some limitations of the school, namely in the sphere of engaged living of the students, where in the case of one third of the students we found this indicator to be on a low level.

\subsection{Social indicators (awareness of own success in school, social popularity and} influence, loneliness and social dissatisfaction, attitudes to oneself and to the school)

The awareness of students' own success at school is high, both of the mainstream students and the students with special educational needs. However, in the case of mainstream students, we found a higher degree of awareness of own success at school, but not on a statistically significant level.

The students of the inclusive secondary school can be characterized by an overall low level of loneliness and social dissatisfaction, and depending on the particular school classes, it was not statistically significant. Hence, neither of the two groups of students, i.e. the mainstream students and the students with special educational needs, feels lonely at school, and both groups of students have good mutual contacts. To some extent, the mainstream students have higher social influence, but from the point of popularity in class, there are no differences. Again, this is a favourable result for the inclusive school. It enables the statement that in the inclusive school, special attention is devoted to positive evaluation of students, to praising them, and that bullying based on handicap is prevented and blocked, what increases the belief in self, as well as the belief in the self-evaluation of students.

Also, we were interested in the attitudes of the mainstream students and the integrated students to their "self", to the school and to their classmates. We have found out that more than one half of the students have a positive attitude to their "self", to the school and to their classmates. However, their attitude to their "self" differs with regard to the year of studies; a distinctly more positive attitude to their self is held by the students in the last two years, which indicates the impact of positively oriented education stressing the appraisal and appreciation of students. A positive attitude of the students to the teachers and classmates, regardless of the year of their studies, their gender or integration, was also manifested.

A statistically significant difference between the level of social support among the students of the inclusive school and the standard school of the same type was also manifested, which was in favour of the inclusive school. At the same time, 


\section{Acta Technologica Dubnicae \\ volume 6, 2016, issue 3}

this testified not only to the importance of the support by parents and friends, but also to the support by the school psychologist. The results accounting for a positive relationship between social support and the overall social-emotional (mental) health, as well as the results regarding the particular psychological indicators (belief in self, belief in others, emotional competences, and engaged living). It seems that social support positively influences the mental health of students, which is interesting and inspiring.

\section{Discussion}

The first results of the research indicate that the inclusive secondary school and inclusive education are functioning within the intentions of positive psychology with regard to all the students. Regardless of whether they have or do not have special needs, they, above all, help them in developing their social-emotional health, in creating appropriate attitudes to their differences, and positive attitudes to their selfs, to their classmates and teachers, help them in forming positive values and the scale of students' values, and in supporting positive interpersonal relationships, social cohesion and the social climate in classes.

After the pilot assessment of the inclusive school, which is currently continuing, it is already evident that an inclusive school faces higher requirements than a traditional school, which is a result of the heterogeneity of the composition of its students. The increased requirements concern the following areas:

a) Optimum change of the environment, above all the social environment of the school and of the classes;

b) The work of teachers within the overall development of the personality of their students, above all their mental health and the development of their key competences;

c) Cooperation, tolerance and altruism of the students in a class and highquality interpersonal relationships;

d) The cooperation of the teachers and experts of the school who work in multidisciplinary teams aiming at creating a good social climate, good social atmosphere and good relationships between teachers and the students, however, with adequate demands and requirements taking into account their results in their studies;

e) Intensive cooperation of the school and families by means of nontraditional forms of work with the parents of students, and through communication with consideration and respect;

f) Career guidance and counselling in the professional orientation of students and in the process of adequate selection of their further studies and employment; 


\section{Acta Technologica Dubnicae \\ volume 6, 2016, issue 3}

g) Training of teachers and experts in order to gain sufficient knowledge about children with mental, physical and social handicaps, about their behaviour and experiencing of the world around them, while the most recent findings from various fields of psychology (social, developmental, clinical, school, educational, and advisory psychology), special pedagogy, social work or sociology, but also from modern didactics and methods of education of children, above all of children with special educational needs, are important.

In the coming years, within carrying out inclusive education, supporting, implementing it, and increasing its quality, we shall probably come across the following weak points:

- Assistant teachers are not qualified for working with children with special educational needs;

- The parents of the mainstream children do not understand the merit of inclusive education;

- During out-of-school education (hiking, cultural events, etc.), the wider public at first does not have any understanding for students with special educational needs;

- School directors are not inclined to accept students with special educational needs if they consider a student's behaviour to be too "disruptive" for other students, as being worried about what the reactions of the parents of the other students will be;

- Class teachers does not "feel" to be qualified for teaching an inclusive class;

- Class teachers state that the assistant disturbs them when communicating with students during classes;

- Parents require the application of the same principles within the educational process as they use at home;

- Schools do not have sufficient material-technical equipment for inclusive education (e.g. easy-access entrance adapted for wheelchairs);

- Teachers are not sufficiently motivated to do their best in favour of inclusive education.

\section{Conclusions}

The basis of inclusive education is creating conditions for the meaningfulness of the educational process for all the students, motivating them to study and to provide to them with appropriate stimuli for supporting their individual development. 


\section{Acta Technologica Dubnicae \\ volume 6, 2016, issue 3}

The main goal of inclusion is the social adaptation of the individuals with any health-related or social handicap. For fulfilling this goal, it is necessary to create such conditions for education which support the optimum development of knowledge and abilities (i.e. internal resources) of both the students with a handicap and the mainstream students, the parents, the teachers, the members of the managerial team, etc.

Although inclusion in Slovak schools depends on the educational policy, educational acts, financial subsidies, material conditions, on the training of teachers and other specialists, it above all concerns the attitudes of all of us, the values, tolerance, sincerity, confidence, altruism, and the acceptation of otherness.

\section{References}

Asher, S. R., \& Wheeler, V. A. (1985). The loneliness and social dissatisfaction questionnaire (LSDQ).

Barancová, M., Bisaki, V., Radnoti, E., \& Sodomová, S. (2014). Inkluzívna škola - príklad dobrej praxe. In E. Gajdošová (Ed.), Psychológia - škola inklúzia (pp. 321-326). Nitra: Polymédia.

Daniels, H., \& Gardner, P. (Eds.). (1999). Inclusive education: supporting inclusion in education systems. London: Kogan Page Limited.

Furlong, M. J., Gilman, R., \& Huebner, E. S. (Eds.). (2014b). Covitality: A synergistic conception of adolescents' mental health. Handbook of positive psychology in the schools (second edition). New York, NY: Routledge/Taylor\&Francis.

Furlong, M. J., You, S., Renshaw, T. L., Smith, D. C., \& O’Malley, M. D. (2014). Preliminary development and validation of the Social and Emotional Health Survey for secondary students. Social Indicators Research, 117, 1011-1032. doi:10.1007/s11205-013-0373-0

Gajdošová, E. (Ed.). (2014). Psychológia - škola - inklúzia. Bratislava: PEVŠ.

Gajdošová, E., \& Bisaki, V. (2015). Aplikácia pozitívnej psychológie v škole. In Rozhodovanie vživote človeka (pp. 62-70). Proceedings from 33. Psychologické dni, Piešt'any, September 3 - 4, 2015. Bratislava: SAV.

Gajdošová, E., \& Bisaki, V. (2015). Rola školského psychológa v kontexte pozitívnej psychológie. Školský psychológ/Školní psycholog. Novinky v pedagogické a školní psychologii, 16(2), 96-100.

Gajdošová, E. (2015). School psychology and school psychologist for the 21st century. Praha: Wolters Kluwer.

Gajdošová, E., \& Radnoti, E. (2016). Social and Emotional Health of Students in the Slovak Republic. Book of Abstracts from 36. ISPA Conference in Amsterdam, July 19 - 22, 2016.

Goleman, D. (1997). Emotional Intelligence. Praha: Columbus. 


\section{Acta Technologica Dubnicae \\ volume 6, 2016, issue 3}

Goleman, D. (1998). Working with emotional intelligence. New York: Bantam Books.

Mareš, J. (2001). Pozitivní psychologie: důvod k zamyšlení i výzva. Československá psychologie, 45(2), 97-117.

Matějček, Z., \& Vágnerová, M. (1992). Dotazník sebapoňatia školskej úspešnosti detí SPAS. Bratislava: Psychodiagnostika.

Nielsen, H. W. (2014). Inclusion. Challenges and Opportunities. In E. Gajdošová, (Ed.), Psychológia - škola - inklúzia (pp. 47-51). Proceedings form international conference, Sept. 4 - 5, 2014. Nitra: Polymédia.

Seligman, M. E. P., Csikszentmihalyi, M. (2000). Positive psychology: An introduction. American Psychologist, 55, 5-14.

Schmidtová, M. (2013). Inkluzivna škola - ako na to? Bratislava: Člověk v tísni - Branch Office Slovakia, Centrum pre výskum etnicity a kultúry.

Vančová, A. (2008). Integrácia a inklúzia osôb s postihnutím, narušením alebo znevýhodnením vkontexte edukácie vkomparácii sich segregáciou (vybrané kapitoly). Bratislava: Mabag.

You, S., Dowdy, E., Furlong, M. J., Renshaw, T., Smidt, D. C., \& O’Malley, M. D. (2014). Further validation of the Social and Emotional Health Survey for high school students. Applied Quality of Life Research, 9, 997-1015. doi:10.1007/s11482-013-9282-2

Zelina, M. (2014). Inkluzívna škola. In E. Gajdošová (Ed.), Psychológia - škola - inklúzia (pp. 207-211). Proceedings form international conference, Sept. 4 $-5,2014$. Nitra: Polymédia. 